\title{
AMERICAN WOMEN MARRY ABROAD
}

The following letter was written by Mrs. A. D. Lee, the widow of David Lee, a prosperous New York merchant of a century ago. Three of their daughters married abroad, two of them into the German nobility, namely Josephine, who married Baron August von Waechter, representative of the King of Wurtemberg at the French court about the middle of the 19th century, and Mary Esther, Countess Waldersee, who figures in this letter. Mary was born in 1837 , went as a young woman to live with her older sister in Paris, and there married Prince Frederick of Schleswig Holstein, who had been driven into exile by the Austro-Prussian army in 1864. She induced him to give up his rights and titles as a member of the Danish royal house, and they were known as the Prince and Princess Noër, from the name of his principal estate. He died while on a visit to the Holy Land in 1865, shortly after their marriage. She returned to Paris, to remain until the outbreak of the Franco-Prussian war drove her and her sister to Würtemberg. In 1871 Mary married Alfred Count Waldersee, who subsequently became Moltke's principal assistant on the general staff at Berlin, and in 1888 his successor as chief of staff. Among his distinguished assignments was the command of the joint European forces which defended the legations in Peking during the Boxer uprising in 1900 .

The Countess Waldersee was a woman of genuine religious temperment, full of good works, much involved in the affairs of the court church, and a friend of both the emperors and their wives. Mrs. Lee was apparently living with her daughter, not only at the time this letter was written but for a number of years, for the Count's Denkwürdigkeiten, posthumously published in 1922-25, contain several affectionate and appreciative references to his mother-in-law, whose death he records as of March 30,1898 , at the age of ninety-seven. She was eightyseven when she wrote this letter, which seems in its note of anti-semitism and Prussian militarism curiously to foreshadow the great crises of half a century later. 
Copyright of Annals of Iowa is the property of State of Iowa, by \& through the State Historical Society of Iowa and its content may not be copied or emailed to multiple sites or posted to a listserv without the copyright holder's express written permission. However, users may print, download, or email articles for individual use. 